\title{
Legislating Without Constraints: The Effect of Minority Districting on Legislators' Responsiveness to Constituency Preferences
}

\section{Citation}

Gay, Claudine. 2007. Legislating without constraints: The effect of minority districting on legislators' responsiveness to constituency preferences. Journal of Politics 69, no. 2: 442-456.

\section{Published Version}

http://dx.doi.org/10.1111/j.1468-2508.2007.00542.x

\section{Permanent link}

http://nrs.harvard.edu/urn-3:HUL.InstRepos:3352699

\section{Terms of Use}

This article was downloaded from Harvard University's DASH repository, and is made available under the terms and conditions applicable to Other Posted Material, as set forth at http:// nrs.harvard.edu/urn-3:HUL.InstRepos:dash.current.terms-of-use\#LAA

\section{Share Your Story}

The Harvard community has made this article openly available. Please share how this access benefits you. Submit a story.

Accessibility 
Gay

\title{
Legislating Without Constraints: The Effect of Minority Districting on Legislators' Responsiveness to Constituency Preferences
}

\author{
Claudine Gay \\ Professor \\ Harvard University \\ Cambridge, MA. 02138 \\ cgay@gov.harvard.edu \\ Department of Government \\ 1737 Cambridge St. \\ Cambridge, MA. 02138
}

For useful comments and criticisms the author thanks David Brady, Jim Fearon, Morris Fiorina, John Griffin, Vincent Hutchings, Simon Jackman, Terry Moe, Ken Scheve, Eric Schickler, and Mike Tomz. Special thanks to Chris Afendulis and Keith Poole for help in the earliest stages of this project. 


\begin{abstract}
Numerous critics have charged that the practice of minority districting, by weakening the electoral incentives central to representative behavior, leads legislators to be less responsive to constituency opinion. Using data on referenda and initiative voting to estimate constituency preferences in each of California's 80 Assembly districts, I assess the correspondence between district opinion and roll call voting for legislators from majority-minority and majority-white districts. I show that constituency preferences can explain the voting decisions of legislators equally well across districts. Despite the low levels of competition and voter turnout found in majority-minority districts, legislators from these districts are no less responsive to the policy demands of their constituents.
\end{abstract}


For more than two decades, the creation of majority-minority districts has been an important tool for increasing the representation of minority interests in state legislatures and the US Congress. Where minority voters are concentrated in numbers sufficient to "elect representatives of their choice," legislators are expected to be uniquely responsive to the policy preferences of these non-white constituents. The empirical evidence suggests that (Democratic) legislators from majority-minority districts in fact are more likely to support a progressive public policy agenda, including initiatives thought to benefit minority Americans in particular (e.g., Hero and Tolbert 1995; Lublin 1997). Yet the practice of minority districting is not without its critics. A number of observers have argued that the electoral security enjoyed by legislators from majority-minority districts undermines the legislative responsiveness such districts were meant to ensure (Guinier 1994; Swain 1995; Thernstrom 1987). With low turnout and few contested elections, majority-minority districts may insulate incumbents from the consequences of failing to respond to the will of their constituents, allowing these legislators more discretion in policy decisions. Rather than reproduce their district's majority opinion, legislators from majorityminority districts instead may follow their hearts or perhaps yield more readily to intra-party pressures. At issue is not whether these legislators tend toward liberalism, particularly on issues salient to non-white constituents; on that point, there is little disagreement. The question is how closely this voting behavior corresponds to the expressed preferences of the constituents they represent. To what extent do constituents determine the policy decisions of legislators from majority-minority districts?

This paper considers the effect of minority districting on legislators' responsiveness to constituency opinion. Comparing legislators from majority-minority and majority-white districts, I measure how closely roll call behavior, including the well-documented tendency 
toward liberalism among majority-minority representatives, reflects the expressed preferences of district voters. I examine, in particular, the correspondence between legislators' voting patterns in the California State Assembly and citizens' votes on statewide ballot propositions, a measure of constituency preferences that is more direct and multidimensional than the demographic proxies commonly used in the literature on minority districting. The analysis finds no substantial difference across districts in the effect of constituency opinion on legislative behavior. Constituency preferences explain the vote choices of legislators from majority-white and majority-minority districts equally well. Moreover, liberal (or conservative) shifts in constituency opinion produce equally large shifts in the ideological positions of legislators from majority-minority and majority-white districts. Despite the electoral security offered by majority-minority districts, legislators from these districts are no less responsive to the policy demands of their constituents.

\section{Minority Districting and the Problem of Electoral Security}

In the debate over the merits and legitimacy of racial redistricting, critics of majorityminority districts often point to the unintended consequences of concentrating minority voters, typically African Americans and Latinos, in districts where they comprise more than 50 percent (and often more than 65 percent) of the population. Attention has focused, in particular, on the limited electoral competition and low voter turnout that are widely viewed as defining features of districts with Black or Latino majorities. Because race and ethnicity are important predictors of partisan vote choice, with blacks and most Latino subgroups reliably supporting Democratic candidates, the number of non-white voters in a district has a significant negative effect on the level of competition (Weber 2000). Not only does the partisan imbalance characteristic of 
heavily minority districts contribute to uncompetitive general elections, but incumbents from “packed, safe districts” (Guinier 1994) rarely face strong primary challengers (Canon 1999). ${ }^{1}$

This lack of competition, in turn, is partly responsible for the low voter turnout observed in majority-minority districts (Brace et al. 1995). By exposing the irrelevance of turnout to electoral outcomes, uncompetitive districts discourage participation and reduce the incentive for candidates or parties to mobilize voters (Campbell 1996). Turnout in minority districts is inhibited still further by the social and economic dislocation common to areas with large black and Latino populations; these districts often pack together residents who lack the resources, namely education and income, known to facilitate participation (Gay 2001). ${ }^{2}$ The unique opportunity that majority-minority districts offer for minority electoral self-determination only partially offsets, at least among non-white voters, the decrease in turnout associated with noncompetitive electoral environments (Barreto, Segura, and Woods 2004; Gay 2001). Among white residents, voter turnout in majority-minority districts is lower than that observed in similarly uncompetitive and socio-economically disadvantaged districts (Gay 2001). Hence, in 1994, over 60 percent of the contested majority-minority congressional districts ranked in the lowest quintile in terms of voter participation (Campbell 1996).

With limited competition and low voter turnout, Swain (1995) and others contend that racial redistricting effectively immunizes legislators against the electoral incentives considered central to representative behavior. Relieved of the preoccupation with reelection, legislators from heavily minority districts are said to enjoy more freedom in their decision-making, less constrained by the need to reproduce their district's majority opinion—or even to invest much effort in legislative work-in order to secure the majority of the vote. While this "immunity" may contribute to either ideological or participatory shirking — for example, Swain (1995) 
describes a legislator nicknamed "The Phantom" for his record of absenteeism and failure to sponsor many bills - attention has focused on its implications for the policy congruence between legislators and constituents. This article as well is concerned strictly with policy voting.

To date, the evidence suggesting that the weak electoral constraints in majority-minority districts compromise the relationship between constituency preferences and legislative behavior is limited and often anecdotal. ${ }^{3}$ In arguing that legislators from majority-minority districts have "great personal freedom to advance their own personal political agendas," Swain (1995) cites the examples of legislators whose defense of the Soviet Union (George Crockett of Detroit) or reticence on civil rights (Robert Nix of Philadelphia) put them at odds with opinion in their districts; legislators whose policy activism, while not directly at odds with district opinion, is focused primarily on issues (e.g. foreign aid) that do not bear on the interests of their constituents; and legislators who vow to place institutional or party responsibilities above their responsibilities to their districts (William Gray of Philadelphia). But there are also examples of legislators from majority-minority districts who do not pursue such an individualistic style, choosing instead to seek close counsel with constituents (Canon 1999; Fenno 2003). Equally telling are the examples of legislators—including Swain's (1995) "Phantom"—whose lack of responsiveness eventually is met by crushing defeat in subsequent primary elections. Whatever freedom these districts afford their elected representatives, it remains unclear whether the strategy of concentrating minority voters, on balance, has a negative effect on the caliber of policy representation.

Despite a vast literature on representation in majority-minority districts, questions about the strength of the relationship between constituency preferences and legislative behavior in these districts have not been addressed directly. In fact, empirical tests of constituency influence 
on legislative decision-making rarely reach beyond an examination of the correspondence between a district's percent minority—considered an indicator of district opinion and ideological tendencies - and roll call voting. Thus, attention has focused on the propensity of legislators from districts with sizable minority populations to vote for or against progressive legislation in general and bills favored by minority interest groups in particular (e.g. Hero and Tolbert 1995; Lublin 1997). This research has established that the size of the minority population is positively correlated with progressive voting, a result cited as evidence of legislators' responsiveness to constituency preferences.

But the relationship between minority population size and roll call voting, while making clear that legislators elected from predominantly minority (read: liberal) districts are more likely to support a liberal public policy agenda than are legislators elected from predominantly white (read: conservative) districts, does not resolve whether constituency influence on legislative decision making is equally strong across districts. To the contrary, models that specify a single, linear relationship between percent minority and roll call voting assume, by definition, that constituency influence is stable. Notably, several scholars have departed from this approach, identifying a host of factors - including region, legislator's race and party, and nature of the vote - that alternately enhance or diminish constituency influence on legislative decision making (Hutchings 1998; Hutchings, McClerking, and Charles 2004; Whitby 1997; Whitby and Krause 2001). This research, however, has not considered minority districting among the factors that condition the behavior of legislators vis-à-vis their constituencies. To what extent are the policy choices made by legislators from majority-minority districts influenced by constituency opinion? The tendency toward liberalism aside, what is of interest here is how constituency influence may wax and wane with the size of the minority population. 
Expectations regarding the effect of minority districting on legislators' responsiveness to constituency preferences depend, in part, on beliefs about the mechanisms of constituency influence. Implicit in the concerns expressed about the deleterious, if unintended, consequences of minority districting is a model of representation in which constituency influence results from legislators' efforts to represent their constituents' positions in order to win reelection. Research on Congress provides empirical support for the general proposition that legislators are motivated by their desire for reelection and that such concerns govern their responsiveness to public opinion (e.g., Ansolabehere et al. 2001; Griffin 2006; but see Bartels 1991). One indication of the importance of the "electoral connection" is recent evidence showing a high incidence of ideological (and participatory) shirking among legislators serving their last term in office (Rothenberg and Sanders 2000). The electoral quietude that comes with concentrating minority voters removes the chief incentive legislators have for following public opinion: the probability of enhancing their reelection prospects. Unencumbered by reelection concerns, legislators from majority-minority districts are freer to focus on their own conception of the common good and to vote in ways contrary to public opinion. Ironically, to the extent that legislators from majorityminority districts also benefit from what one legislator described as "the blind faith" (Fenno $1977,912)$ that comes from descriptively representing their constituents, immunity from electoral concerns means in effect that majority-minority legislators feel unconstrained by constituents who may nonetheless feel "close" to and "proud of" them (see also Tate 2003). As one such legislator explained, "My constituents don't know how I vote, but they know me and they trust me" (as quoted in Fenno 1977, 912; italics in original). If the threat of electoral defeat is the primary mechanism by which constituents can influence legislative decision making, then 
the logical expectation is for minority districting to weaken the relationship between constituency opinion and legislative behavior.

The threat of electoral defeat, however, is one of two mechanisms available to constituents for ensuring legislators' responsiveness to their preferences. Constituents may also exert influence over legislators by electing like-minded representatives, a pattern more common in ideologically homogenous districts (Erikson 1978; Fearon 1999; Hutchings, McClerking, and Charles 2004). Legislators whose own preferences mirror those of their constituents can be expected to make policy decisions consistent with district opinion. Whether they represent districts that are "cheap seats" (Campbell 1996), with limited electoral competition and low voter turnout, is irrelevant. Even when their reelection prospects are not at stake, the level of responsiveness would be high. The same legislator who considered himself unconstrained by his constituents, also viewed himself as a "microcosm" of his district:

I don't have any trouble knowing what [the district] thinks or wants... When I vote my conscience, I vote right for the district. If I voted against civil rights legislation, my people would probably ask me why I did that. But I never would do it (as quoted in Fenno 1977, 912).

Thus, the expectation, based on this conception of constituency influence, is that the relationship between constituency opinion and roll call voting will be as strong in majority-minority districts as elsewhere.

\section{Measuring Constituency Preferences and Legislative Responsiveness}

In order to compare districts on the strength of the relationship between legislator's voting record and constituents' preferences, the first challenge is to identify a reliable measure of constituency opinion. With few exceptions, scholars have relied on select social and economic characteristics — such as racial composition, urbanism, median household income - as proxies for district opinion, the assumption being that voters' non-policy attributes correlate with their 
policy preferences and that majority opinion in a district can be described by an additive linear function of these attributes. At best these measures are blunt tools. For the questions examined here, they also are of limited analytical use. Once districts are sorted by their majority-minority or majority-white status, there is insufficient variation on the demographic indicators (particularly among majority-minority districts) to differentiate effectively among the districts within each category. The lack of demographic variation may conceal substantive differences in constituency opinion, leading us to underestimate the correspondence between opinion and roll call voting. Furthermore, using racial composition to both classify districts and to measure district opinion makes it impossible for demographic characteristics and electoral environment to be assessed separately from district opinion as influences on legislators' decisions. The challenge is to identify a measure of constituency opinion that is more precise and informative than the demographic surrogates, and that allows for its effects to be separated adequately from other features of a district.

Several scholars have proposed the use of referendum voting returns as an alternative to the reliance on demographics for measuring constituents' preferences (Gerber and Lewis 2004; Kuklinski 1978; Lewis 1998; McDonagh 1993; Snyder 1996, 2005). This approach offers several advantages that make it well suited to the questions examined here. Rather than the inferential leaps implicit in the use of demographic proxies, citizens' choices on ballot initiatives and referenda are behaviors that directly express their policy preferences (Kuklinski 1978). ${ }^{4}$ As votes on specific policy proposals and as decisions with real lawmaking consequences, these vote choices are in important ways comparable to representatives' roll call votes. When aggregated, information from initiatives and referenda capture multiple dimensions of constituency preferences, with more specificity than a linear combination of a district's socio- 
economic characteristics. The result is a more precise description of the preference signals that the public sends to policy makers. ${ }^{5}$ In addition to enabling sharper inferences about constituency opinion, preference measures derived from votes on ballot propositions make it possible to disentangle demographic characteristics from constituency opinion as influences on legislative behavior. In evaluating whether legislators in majority-minority and majority-white districts respond equally to the will of their constituents, I use voting returns from propositions to measure constituency preferences.

With constituency preferences measured, I assess legislative responsiveness on the basis of how effectively constituency preferences predict roll call voting. Specifically, I compare legislators from majority-minority and majority-white districts on the predictive power of the preference estimates and on the magnitude of their effects on voting behavior. In models of roll call voting, the coefficients on the preference estimates capture, at least in a statistical sense, the extent to which public preferences directly influence policy voting. If legislators from minority districts exercise more discretion in their decision-making, free from the electoral concerns that constrain the choices of other legislators and ensure their responsiveness, then we would expect to see significant differences in the predictive power of the preference estimates across types of districts; less predictive in majority-minority districts, more in majority-white. While roll call votes may not be directly at odds with constituency preferences in majority-minority districts, the measured effect of preferences on voting should be relatively small compared to its effect among legislators from majority-white districts. However, if constituents from majority-minority districts are successful in electing like-minded legislators, then despite the electoral quietude of these districts we would not expect significant differences in the predictive power or estimated effects of constituency preferences. 
Even with the benefit of more refined estimates of constituency preferences, this analysis confronts an inferential challenge common to all correlational studies of representation (see Achen 1978). Votes on referenda and initiatives may be commensurate with but are not directly comparable to roll call votes. As a result, the statistical correlation between constituency preferences and representatives' voting patterns indicates only the relative, not absolute, degree of correspondence between the two. With constituency preferences and legislative behavior measured on different scales, it is possible to estimate a high correlation even if, as Snyder (1996) points out, "all representatives are to the left of their constituents' mean ideal point" (482). Yet, for the questions examined here, the relative degree of correspondence is a useful statistic in comparing the responsiveness of legislators across districts. Importantly, whatever caveats apply to correlational studies of this kind, apply equally to the analysis of majorityminority and majority-white districts and, hence, can not account for any differences observed between these district types; such differences are the sole concern of this article.

\section{Data and Estimation of Constituency Preferences}

I study legislative responsiveness with data from California, measuring the effect of constituency opinion on roll call voting behavior during the 1997-1998 session of the California State Assembly. The state is selected for several reasons. Because of its widespread use of the initiative process, California offers a wealth of information - to researchers and politiciansabout voter preferences on a wide range of major policy issues. The State Assembly, a highly professional body whose many similarities to the U.S. House enhance the generalizability of the results, provides a particularly useful context for the study of minority districting and legislative responsiveness. Not only is the Assembly sufficiently large ( 80 members) to allow for some confidence in statistical analyses, but also the legislators represent a diverse mix of districts, 
including (as of the 1997-1998 session) 27 with a majority non-white general population. These districts included 10 majority-Latino districts and 17 districts in which no single racial or ethnic group accounted for more than half of the population. (In three of the heterogeneous districts, African Americans, while not a majority, constituted the largest minority group.) Moreover, the majority-minority Assembly districts exhibit the same pattern of limited competition and low voter turnout that is commonly associated with congressional and state legislative districts with large minority populations, and that critics contend may undermine legislative responsiveness. ${ }^{6}$

I derive estimates of constituency preferences from votes on statewide ballot propositions in the November 1996 election, which immediately preceded the 1997-1998 Assembly session. The voting data is aggregated to the level of the assembly district. Fifteen propositionsincluding three referenda (all bond measures) put on the ballot by the Legislature, and 12 initiatives put on the ballot by petition—were voted on in that election. Measures that posed questions similar to other propositions on the ballot were excluded from the analysis. ${ }^{7}$ The remaining 14 ballot measures covered a range of issues, from civil rights to taxation, campaign finance reform, health policy, and prison construction.

The district-level proposition vote percentages were subjected to factor analysis in order to recover the policy dimensions responsible for the systematic variation in proposition support across districts (Snyder 1996, 2005). By scaling the proposition votes, I derive measures of general constituency preferences that are more efficient than using all 14 propositions directly, and more informative than demographic proxies. To improve the estimation of the policy dimensions, I include in the factor analysis an additional measure of constituency opinion, the district-level Democratic vote for president. A maximum-likelihood factor analysis, with the data weighted by voter turnout in the assembly district (Snyder 1996), yielded a three-dimensional 
spatial model. The first factor accounted for 73 percent of the cross district variance; the addition of the second increased the percent of variance explained to 89 percent. The uniqueness values were generally low; for ten of the 15 measures, less than 15 percent of the vote variance was unexplained by the three-factor model.

The varimax-rotated factor loadings describe the information contained in each factor (and, by extension, the relative characteristics of each proposition), offering some insight into the substantive interpretation of the spatial dimensions. The first factor loads primarily (i.e. loadings over .65) on three propositions: a proposal barring the legislature from imposing any restrictions on the rights of attorneys and clients to negotiate fees, including contingent fee arrangements; a proposal imposing civil liabilities and authorizing class action suits when securities fraud results in losses to individuals' investments; a health care measure creating a non-profit consumer watchdog agency and barring insurers and HMOs from conditioning coverage on patients' agreement to arbitration. The pattern of loadings suggests that this first dimension may capture preferences on Consumer Populism. District scores on this first dimension vary with population characteristics such as Democratic registration (positively) and region (highest in Southern California districts).

The second factor loads primarily on eight ballot propositions, as well as on the Democratic vote for president: a bond issue to improve waterways, and impose water conservation and flood control measures; a bond issue to provide farm and home aid to California veterans; a constitutional amendment prohibiting affirmative action in public employment, education, and contracting; a proposal to raise the minimum wage by $\$ .75$; a proposal denying recovery of damages to convicted felons, drunk drivers, and uninsured motorists in the event of a car accident; a proposal limiting health insurers' ability to deny care, 
and increasing staffing requirements at health facilities; a proposal to increase the tax rate on the highest income taxpayers; and a constitutional amendment requiring voter approval for any increase in property tax rates. With factor loadings exceeding .90 for votes on affirmative action, the minimum wage, and Bill Clinton's reelection, I interpret this dimension to be a measure of constituency Liberalism. ${ }^{8}$ That most of the propositions address economic, as opposed to social, issues suggests the dimension captures Economic Liberalism in particular. District scores on the second factor vary predictably with population characteristics. The scores are positively correlated with Democratic registration, the proportion college-educated, and the proportions Asian and Latino. (Proportion black is positively correlated but not statistically significant.) There is also statistically significant regional variation, with the highest scores in Northern California and the lowest in Central California. These variables explain 87 percent of the variation in Economic Liberalism.

The third factor loads primarily on only two propositions - a campaign finance measure limiting contributions to political candidates and imposing voluntary spending caps, and a proposal legalizing the medical use of marijuana — which makes it difficult to interpret. Moreover, the uniqueness value on one of the measures, the campaign finance proposal, is very high: 48 percent of the vote variance on Proposition 208 is unexplained by the spatial model. Because this factor is not well specified — and, in fact, may measure nothing more abstract than opinion on medical marijuana-I exclude it from the analysis of legislative responsiveness.

Finally, none of the three factors loads on Proposition 205, a bond issue to finance prison construction (mostly in the Central Valley); the measure has a uniqueness value of .89. The district vote on this measure varies only with district location (strong support in the Central Valley, weak elsewhere), suggesting that it is strictly a regional issue. 
Figure 1 plots the scores of majority-minority and majority-white assembly districts on the first and second dimensions. Districts that include all or part of the state's better-known cities are indicated. On balance, majority-minority districts have higher values on both the Economic Liberalism and Consumer Populism dimensions, a structure that is intuitively reasonable. Importantly, however, even among majority-minority districts there is variation in constituency preferences, especially on issues related to consumer rights. Moreover, a number of majority-minority districts hold high values on the liberalism dimension, but relatively low values on the consumer dimension. For example, in Norwalk's (Los Angeles County) $58^{\text {th }}$ Assembly district, which is 70 percent non-white, constituency opinion on Consumer Populism is more similar to opinion in majority-white districts in San Diego and Hayward than to opinion in most minority districts, including those in Santa Ana and Fresno with similar demographic characteristics. Yet, in terms of Economic Liberalism, constituency opinion in Norwalk does not depart substantially from opinion in most minority districts. The graphs also reveal the existence of majority-minority districts (e.g. San Jaoquin Valley's $30^{\text {th }}$ ) where constituents exhibit centristto-Conservative tendencies in both their general ideology and their particular opinions regarding consumer rights. Such patterns further underscore the limits of demographic proxies as indicators of constituency preferences. Constituency preferences are multidimensional and diverse.

\section{[FIGURE 1 ABOUT HERE]}

\section{Responsiveness to Constituency Preferences: Predicting Roll Call Votes}

Using the factor scores as measures of constituency preferences, I now consider their relationship to legislators' voting behavior, and the effect of minority districting on this linkage. Specifically, I examine whether districts' scores on Consumer Populism and Economic Liberalism predict roll call voting during the 1997-1998 Assembly session. I examine each roll 
call separately, estimating a logit regression - with the two constituency factor scores as predictors - for each of 1614 non-unanimous Assembly floor votes. ${ }^{9}$ While district-wide constituency preferences in general, and these two imperfect measures in particular, are not likely to affect legislators' votes on every bill, if constituency preferences matter most of the time, then across many roll calls these preferences should explain a substantial share of legislators' decisions. ${ }^{10}$ For that reason, I present summary statistics of the logit results, focusing on the average predictive power of the constituency preference measures.

Table 1 presents statistics for two measures of goodness of fit: the (average) percent of roll call votes correctly classified, where "correct" indicates that the model assigned a probability greater than .5 to the member's actual vote choice; and the (average) proportional reduction in error (PRE), which measures the relative improvement in classification success over the benchmark prediction that the member simply votes with the majority. ${ }^{11}$ On average, constituency preferences on economic and consumer rights issues predict legislators' voting patterns in the 1997-1998 session well. The logits correctly classified an average of 88 percent of the votes cast on the non-unanimous roll calls considered. The PREs are also quite high: on average, including the constituency preference measures improves the ability to predict legislators' voting decisions by 46 percent. These summary statistics compare favorably with the results of a party-line voting model, in which legislators are predicted to vote with their party's majority. With similar classification rates and PREs, districts' scores on Consumer Populism and Economic Liberalism appear to be at least as effective as members' party affiliations in predicting roll call behavior. Finally, for 91 percent of the sampled roll calls, $\chi^{2}$ likelihood ratio tests reject the hypothesis of a chance relationship between constituency preferences and roll call voting at the five percent level. 


\section{[TABLE 1 ABOUT HERE]}

Within each party delegation, the predictive power of constituency preferences is reduced, evidence that constituency influences on legislative behavior operate largely through their effect on the party affiliation of the elected representative. ${ }^{12}$ Note that after controlling for party, the number of non-unanimous roll calls (i.e. non-unanimous within each party's caucus) declines dramatically—especially for Democrats (85\%), less so for Republicans (34\%). Nonetheless, even after taking party affiliation into account, constituency preferences remain significant predictors of roll call voting. Of primary interest is the roll call behavior of Assembly Democrats, who represented 21 of California's 27 majority-minority districts. For the subset of roll call votes (250) on which the Democratic caucus was not unanimous, models of voting behavior that include constituency preferences on economic and consumer rights issues improve predictions by 10 percent on average. In 22 percent of these roll calls, the relationship between the preference measures and Democrats' voting behavior is statistically significant at the five percent level.

Assembly Democrats from majority-minority districts are no less responsive to constituency preferences than legislators from majority-white districts. To begin, the sets of nonunanimous roll calls are equally small for both groups of legislators; despite the variability in constituency preferences documented in Figure 1, Democrats from majority-minority districts, like those from majority-white districts, were unanimous on over 80 percent of roll calls. Where Democrats disagree, the logit results show only small differences in the predictive power of the Consumer Populism and Economic Liberalism scores based on the majority-minority status of the district. The average PRE for the subset of roll calls (263) on which Democrats from majority-minority districts were not unanimous is 18 percent, five percentage points higher than 
the average PRE for Democrats from majority-white districts. For Democrats from majorityminority districts, district opinion is a significant predictor of voting in 14 percent of nonunanimous roll calls, compared with 13 percent of roll calls for majority-white legislators.

That Democratic legislators are equally responsive to public opinion is also apparent from their behavior on the Assembly bills most directly related to specific propositions on the November 1996 statewide ballot. After sorting the non-unanimous roll call votes by subject matter (as determined by the bill's committee of origin), I reestimated the vote choice models, using the district vote on a related ballot proposition rather than the constituency factor scores as the sole predictor. ${ }^{13}$ Table 2 presents results from these logit models. While there are differences across issue areas in the extent to which legislators' votes are guided by constituency opinion - for example, votes on public safety matters are the most closely related to past initiative votes - on most subjects, the vote choices of majority-minority Democrats are at least as responsive to opinion on related initiatives as the choices of Democrats from majority-white districts. Thus, on public safety issues, Propositions 213 and 215 on average improve roll call predictions by 14 and 15 percent, respectively, for majority-minority Democrats and 9 and 7 percent for majority-white Democrats. Moreover, in more than one-third of the (non-unanimous) public safety roll calls, the district votes on these initiatives are statistically significant $(p<.05)$ predictors of vote choice for majority-minority Democrats. By comparison, the initiative votes are significant in only one-eighth to one-fifth of the models for majority-white Democrats. Only for the handfuls of (non-unanimous) roll calls related to health and to revenue and taxation is there evidence that the district vote on specific initiatives is more effective in predicting the voting patterns of legislators from majority-white rather than majority-minority districts. On 
balance, the results from the roll call analysis indicate that majority-minority Democrats are as likely as their majority-white colleagues to sense and respond to relevant shifts in public opinion.

[TABLE 2 ABOUT HERE]

\section{Responsiveness to Constituency Preferences: Predicting Policy Orientation}

The roll call data established that constituency preferences on economic and consumer rights issues, as well as opinion on specific policy proposals, are significant predictors of Assembly voting, and can explain the voting patterns of Democratic legislators from majoritywhite and majority-minority districts equally well. Among these legislators, vote decisions in 14 percent of all non-unanimous roll calls depend in part on their constituents' orientations toward Consumer Populism and Economic Liberalism. And in at least one policy area in particular, public safety, constituents' specific policy preferences, as expressed by their votes on related ballot measures, influence decisions in up to one-third of the legislators' non-unanimous roll calls on the issue. Having determined that preferences affect behavior-presumably, by leading legislators to take more liberal (conservative) positions when district opinion is more liberal (conservative) - I now consider the magnitude of this effect. Do districts' scores on Consumer Populism and Economic Liberalism have as large an influence on the policy positions of legislators from majority-minority districts as on the positions of legislators who represent majority-white constituencies?

Rather than compare effect sizes on individual roll calls, I scale votes to construct a summary measure of legislators' policy positions, and examine the relationship between this measure and the two constituency preference estimates. The summary measure, because it describes a legislator's decisions across a long series of votes, provides more information than any single roll call vote. The measure is also more informative than interest group ratings, which 
typically are limited to a single policy domain and to the highly salient votes within that domain (Snyder 1996). I use Poole's (2000) optimal classification (OC) procedure to estimate legislators' policy positions from their decisions on 3404 roll calls, a sample that includes all votes on all bills originating in the Assembly during the $1997-1998$ session. $^{14}$ (Unanimous votes are not excluded.) Although the estimation procedure allowed for up to two dimensions, the results indicate that a single left-right dimension accounts for most of the variation in roll call voting. ${ }^{15}$ Figure 2 plots legislators' positions on the first and second dimensions, highlighting members from majority-minority Assembly districts. The graph indicates that Republicans, including those who represent majority-minority constituencies, vary more widely across the policy space than do Democrats. The pattern is consistent with the earlier finding that the Democratic caucus is non-unanimous on far fewer roll calls than the Republicans. Democrats as a whole are clustered on the left, with little intra-party variability along the second dimension. Nonetheless, there is evidence of some first dimension variability among Democratic legislators from majority-minority districts. In fact, the policy variance among majority-minority Democrats is slightly larger than the variance among Democratic legislators from majority-white districts.

\section{[FIGURE 2 ABOUT HERE]}

Table 3 presents estimates of the effect of constituency preferences on legislators' policy positions, using the first dimension OC scores as the dependent variable in each regression and the districts' Consumer Populism and Economic Liberalism scores as predictors. For the Assembly as a whole (first two rows), I find a "positive" relationship between district preferences and legislative behavior. On average, legislators representing liberal districts (high constituency factor score) take more liberal policy positions (low first dimension OC score). After including a control for party affiliation, Economic Liberalism remains a statistically 
significant predictor of legislators' left-right position, while Consumer Populism has no effect.

The magnitude of the constituency effect is small: a legislator's policy position shifts by .17 standard deviations for each standard deviation change in preferences on the Economic Liberalism dimension. Given that the constituency preference estimates, even if measured without error, locate voters on two specific policy dimensions, while the scale upon which legislators are located reflects choices across a wide range of policy issues, the small effect size is not surprising. The effect size is also constrained by the high baseline probability of voting with the majority on any single bill; even the non-unanimous roll calls are often quite lopsided.

\section{[TABLE 3 ABOUT HERE]}

The absolute magnitudes of the effects are of less interest here than the relative magnitudes across subgroups of legislators. For example, the results show that the two constituency dimensions are not equally effective at explaining the policy variation within each party caucus. District opinion on Consumer Populism is a statistically significant constituency factor only for Democrats, although its effect on those legislators is small. The coefficients on Economic Liberalism indicate that its effect on the policy positions of Republican legislators is ten times greater than its effect on Assembly Democrats. The model predicts that a one standard deviation shift in economic preferences would shift Democratic policy positions by less than one-twentieth of a standard deviation, but Republican positions by .61 standard deviations.

The correspondence between constituency preferences and legislators' policy positions is unaffected by minority districting. The last two rows of Table 3 report results from separate regressions predicting policy variation among Democratic legislators from majority-white and majority-minority districts. We observe no statistically significant effects associated with district opinion on Economic Liberalism for either group of Democratic legislators. And, to the extent 
that levels of Consumer Populism influence legislators' policy positions at all, it is only Democrats from majority-minority districts whose behavior varies with their constituents' preferences on this dimension. While this effect is statistically significant, its magnitude is substantively small.

Together with the results from the earlier roll call analysis, the findings suggest that minority districting per se is not at odds with legislative responsiveness. Constituency preferences affect the roll call behavior of Democrats from majority-minority districts as often as the behavior of Democrats from majority-white districts. And for both groups, this effect is small when compared to the effect sizes observed among Republicans.

\section{Discussion}

The creation of majority-minority electoral districts is a practice that has provoked considerable debate among scholars, politicians, and jurists alike. In recent years, questions about the implications of this practice for legislative responsiveness have galvanized opposition to these districts from across the political spectrum. In this article, I have examined the oftrepeated claim that minority districting, by weakening the electoral incentives considered central to representative behavior, undermines the relationship between constituents' policy preferences and legislators' policy decisions. Across hundreds of individual roll calls, I show that constituency preferences are as likely to affect the voting decisions of legislators from minority districts as they are the choices of legislators from predominantly white districts. Moreover, when comparing the sizes of these effects, I demonstrate that there are no differences across types of districts. Despite the low levels of competition and voter turnout often found in majority-minority districts, legislators from these districts are no less responsive to the policy 
demands of their constituents. Anecdotal evidence aside, the charges of policy shirking by majority-minority legislators are unsupported.

One might reasonably question whether the responsiveness observed in California's majority-minority Assembly districts is exceptional, an artifact of the racial and ethnic heterogeneity that characterizes many of these districts and that sets them apart from the more segregated, heavily black Congressional districts criticized by Swain (1995) and others. As noted earlier, in 17 of the 27 majority-minority Assembly districts in the state no single racial or ethnic group accounted for more than half of the population; and in only 3 districts were African Americans the largest group. This heterogeneity may be significant for either of two reasons. First, we might expect that with greater racial and ethnic diversity comes greater ideological diversity and, therefore, a more competitive electoral environment (as compared to the environment in majority-black districts). After all, there is perhaps no social group as uniformly liberal and Democratic as African Americans; California's Assembly districts may fall short of the level of ideological homogeneity thought to lead to policy shirking by legislators. Yet while these districts lack the racial homogeneity of the archetypal majority-minority district, by at least one important measure they are no less ideologically homogenous. The average vote for Clinton, in November 1996, in the majority-minority Assembly districts represented by Democrats in California was $78.9 \%$, with a standard deviation of $8.5 \%$; in the oft-criticized majority-black Congressional districts represented by Democrats throughout the country, the average Clinton vote that same year was $78.5 \%$, with a standard deviation of $9.3 \%$. In terms of ideology, California's majority-minority Assembly districts, despite their greater demographic diversity, are not exceptional. 
What may be significant about the racial and ethnic heterogeneity of these Assembly districts — and what may limit our ability to generalize from the results here — is that such heterogeneity, although not a source of greater ideological or partisan competition, may foster racial and ethnic competition, as constituency subgroups compete for descriptive representation. This competition would be most evident in a district's (Democratic) primary, which might feature a racially and ethnically diverse field of candidates, each trying to mobilize a base of coethnic voters large enough to secure victory. Racial competition may be instrumental in motivating the legislative responsiveness observed in California's majority-minority Assembly districts. Thus, caution is in order when generalizing from these results to the behavior in more homogenous majority-minority districts. Future research would benefit from a closer examination of responsiveness in more racially segregated districts.

If, however, it is not racial and ethnic competition that motivates majority-minority legislators in California to follow the will of their constituents, then the findings suggest that constituency influence operates through multiple mechanisms. The literature on Congress is replete with evidence demonstrating that reelection fears are effective in securing responsiveness (Griffin 2006). Yet the threat of electoral defeat may not provide the only guarantee that a legislator will faithfully represent her constituents' policy preferences (Fearon 1999). Constituents in minority districts may exert influence over policy-making not through the threat of electoral defeat, but primarily through the election of like-minded legislators. Having identified and elected political candidates whose preferences mirror their own, constituents ensure that subsequent policy decisions will be consistent with opinion in the district. To the extent that this mechanism of constituency influence prevails in minority districts, perhaps as a 
result of these districts' ideological homogeneity (Erikson 1978), it offsets the risks believed to be associated with electoral security (i.e. an unresponsive legislator).

Other questions remain about the nature of the constituency-representative relationship in majority-minority districts. The empirical analysis is based on a simple model of representation in which legislators seek to reproduce their districts' majority opinion. In light of the multiple constituencies that can exist within districts (Fiorina 1974), a more appropriate model might allow for legislators to discriminate among these constituency groups, according some more attention than others. With that in mind, future research should develop a wider array of constituency preference measures, capturing opinion across more policy dimensions and measuring the distinct preferences of different subgroups of constituents. In addition to providing for a fuller account of the variation in legislators' policy choices, the additional constituency measures might reveal heretofore unknown differences in the voting behavior of legislators from majority-minority and majority-white districts. 
Notes

${ }^{1}$ Canon (1999) finds that the level of candidate activity, as measured by the number and quality of primary challengers, in congressional districts with large black populations is high only when such districts are first created or (to a lesser extent) when there is an open seat; in both cases, candidate activity dramatically declines in subsequent elections. In 1992, there were four times as many candidates per district in newly created black districts as in older ones.

${ }^{2}$ For Latino districts, a large non-citizen population and the relative youth of the population also contribute to low voter turnout.

${ }^{3}$ Moreover, recent research suggests not only that weak electoral constraints are not unique to majority-minority districts (Barreto, Segura, and Woods 2004), but also that most legislators are ideologically extreme relative to their constituents (Ansolabehere et al. 2001).

${ }^{4}$ In this sense, a referendum- or initiative-based measure of constituency preferences is more consistent with the decision-making calculus of legislators, who can perceive these voting choices easily and are likely to value them as tangible information about their constituents' issue positions (McDonagh 1993). Additionally, the measure is derived from the behavior of district voters, the population most salient to a legislator (Kuklinski 1978; Snyder 1996).

${ }^{5}$ The disadvantage, however, is that in any given year citizens may not vote on a wide range of policy issues, thus limiting our ability to generate a complete ideological map of district opinion. An analysis of voting returns can uncover only those constituency dimensions substantively related to at least one ballot proposition. Constituency opinion may vary across additional dimensions. To the extent that other dimensions are factors in legislative decision-making, the inability to measure them would lead us to understate the degree to which legislators' roll-call voting patterns agree with their constituents' preferences. 
${ }^{6}$ In three-quarters of the majority-minority Assembly districts, candidates in the November 1996 elections won with more than 62 percent of the two-party vote; in only 25 percent of the majority-white districts were the winning candidates similarly successful. Turnout among registered voters that year exceeded 60 percent in only a quarter of majority-minority districts, compared with 90 percent of majority-white districts.

${ }^{7}$ Redundant measures, when included, dominate an estimated preference dimension. The redundant measure excluded was Proposition 212, a campaign finance initiative put on the ballot by the California Public Interest Research Group as an alternative to Proposition 208, supported by Common Cause. Of the two measures, I excluded the proposition with the lowest vote variability.

${ }^{8}$ The two health care-related initiatives (214 and 216), which address both consumer rights and expanded coverage, are factorially complex; for each, the Consumer Populism and Economic Liberalism dimensions have loadings above .50 .

${ }^{9}$ The sample consists of all non-unanimous votes (i.e. less than a 95 percent majority, excluding abstentions) on bills authored by a member of the Assembly. The sample excludes votes on constitutional amendments, which must be approved by initiative; concurrent resolutions, which do not require the governor's signature; and joint resolutions, which are non-binding. For each roll call $r$, I estimate the following logit model:

$$
P\left(v_{i}^{r}=1\right)=F\left(\beta_{0}^{r}+\beta_{1}^{r} \text { ConsumerPopulism }_{i}+\beta_{2}^{r} \text { EconomicLiberalism }_{i}\right)
$$

where $v_{i}^{r}$ is the vote of the state legislator from Assembly district $i$ (1 Yea, 0 Nay), and Consumer Populism P $_{i}$ and Economic Liberalism $i$ are the factor scores for district $i$.

${ }^{10}$ Even if legislators always vote their district, there are several reasons why we should not expect to find a perfect correspondence between districts' scores on Consumer Populism and 
Economic Liberalism and legislators' vote choices. First, there is certainly measurement error in the estimates of constituency preferences. The effect is to bias downward the estimated explanatory power of the constituency measures. More generally, Consumer Populism and Economic Liberalism are not the only axes of conflict in the legislature (or, for that matter, in the districts). Legislators may consider a variety of bills that are not substantively related to either of these policy dimensions. On bills that contain neither a consumer rights nor an economic element, vote choices will not be correlated with constituency opinion on these dimensions. Finally, Fiorina (1974) and others argue that legislators are less concerned with the preferences of the median voter in their district than with the preferences of their reelection constituency (see also Bailey and Brady 1998; Lewis 1998; Stratmann 1996). Where this is true, preference estimates based on majority opinion in districts will have limited explanatory power. ${ }^{11}$ The PRE, calculated as (Minority Vote - Model Classification Errors)/Minority Vote, has a value of one if there are no classification errors and zero if the model leads to as many errors as the benchmark predictions (Poole and Rosenthal 1997, 30).

${ }^{12}$ I control for party by estimating separate logit regressions for Republicans and for Democrats. (The number of regressions estimated for a party caucus depends on the number of nonunanimous roll calls for that caucus.) Similarly, I control for the majority-minority status of the district by estimating separate regressions for Democrats from majority-white and from majorityminority districts.

${ }^{13}$ Not every Assembly bill could be matched to one of the 14 ballot propositions. For Democrats, as a whole, I was able to match the bills associated with 64 percent of the non-unanimous roll call votes (160 of 250); for Democrats from majority-white Districts, 62 percent (124 of 200); 
from majority-minority districts, 64 percent (168 of 263). To save space, Table 2 lists only those categories for which each subgroup of legislators had at least 5 non-unanimous roll call votes. ${ }^{14}$ The optimal classification algorithm, because of its ability to accommodate a roll call matrix with higher levels of correct classification (and thus low error rates) proved much better suited to the California Assembly data than the probabilistic W-NOMINATE model (Poole 2000; see Rosenthal and Voeten 2004 for discussion of limitations of W-NOMINATE in the context of near perfect two-dimensional spatial voting).

${ }^{15}$ Conditioning vote decisions on legislators' scores on the first OC dimension produces an overall classification success rate of 96 percent, an 81 percent reduction in error from the benchmark prediction that legislators vote with the majority. 


\section{References}

Achen, Christopher H. 1978. "Measuring Representation.” American Journal of Political Science 22: 475-510.

Ansolabehere, Stephen, James M. Snyder, Jr., and Charles Stewart, III. 2001. "Candidate Positioning in U.S. House Elections.” American Journal of Political Science 45: 136-159.

Bailey, Michael, and David W. Brady. 1998. "Heterogeneity and Representation: The Senate and Free Trade." American Journal of Political Science 42: 524-44.

Barreto, Matt A., Gary M. Segura, and Nathan D. Woods. 2004. "The Mobilizing Effect of Majority-Minority Districts on Latino Turnout." American Political Science Review 98: 6575.

Bartels, Larry M. 1991. “Constituency Opinion and Congressional Policy Making: The Reagan Defense Build Up.” American Political Science Review 85: 457-74.

Brace, Kimball, Lisa Handley, Richard G. Niemi, and Harold W. Stanley. 1995. “Minority Turnout and the Creation of Majority-Minority Districts." American Politics Quarterly 23: 190-203.

Campbell, James E. 1996. Cheap Seats: The Democratic Party's Advantage in U.S. House Elections. Columbus, OH: Ohio State University Press.

Canon, David T. 1999. Race, Redistricting, and Representation: The Unintended Consequences of Black Majority Districts. Chicago: University of Chicago Press.

Erikson, Roberts S. 1978. “Constituency Opinion and Congressional Behavior: A Reexamination of the Miller-Stokes Representation Data.” American Journal of Political Science 22: 51135.

Fearon, James D. 1999. “Electoral Accountability and the Control of Politicians: Selecting Good Types versus Sanctioning Poor Performance”. In Democracy, Accountability, and 
Representation, eds. Bernard Manin, Adam Przeworski, and Susan Stokes. Cambridge:

Cambridge University Press, 55-97.

Fenno, Richard F., Jr. 1977. "U.S. House Members in Their Constituencies: An Exploration.” American Political Science Review 71: 883-917.

Fenno, Richard F., Jr. 2003. Going Home: Black Representatives and Their Constituencies. Chicago: University of Chicago Press.

Fiorina, Morris. P. 1974. Representatives, Roll Calls, and Constituencies. Lexington, Mass: Heath.

Gay, Claudine. 2001. "The Effect of Black Congressional Representation on Political Participation.” American Political Science Review 95: 589-602.

Gerber, Elisabeth R., and Jeffrey B. Lewis. 2004. "Beyond the Median: Voter Preferences, District Heterogeneity, and Political Representation." Journal of Political Economy 112: 1364-83.

Griffin, John. 2006. "Electoral Competition and Democratic Responsiveness: A Defense of the Marginality Hypothesis." Journal of Politics 68: 911-921.

Guinier, Lani. 1994. The Tyranny of the Majority: Fundamental Fairness in Representative Democracy. New York: Free Press.

Hero, Rodney E., and Caroline J. Tolbert. 1995. "Latinos and Substantive Representation in the U.S. House of Representatives: Direct, Indirect, or Non-Existent?” American Journal of Political Science 39: 640-52.

Hutchings, Vincent L. 1998. "Issue Salience and Support for Civil Rights Legislation Among Southern Democrats." Legislative Studies Quarterly 23: 521-44. 
Hutchings, Vincent L., Harwood K. McClerking, and Guy-Uriel Charles. 2004. “Congressional Representation of Black Interests: Recognizing the Importance of Stability.” Journal of Politics 66:450-68.

Kuklinski, James H. 1978. "Representativeness and Elections: A Policy Analysis.” American Political Science Review 72: 165-77.

Lewis, Jeffrey B. 1998. "Who Do Representatives Represent? Estimating the Importance of Electoral Coalition Preferences in California." Ph.D. Dissertation, Massachusetts Institute of Technology.

Lublin, David. 1997. The Paradox of Representation: Racial Gerrymandering and Minority Interests in Congress. Princeton: Princeton University Press.

McDonagh, Eileen L. 1993. "Constituency Influence on House Roll-Call Votes in the Progressive Era, 1913-1915.” Legislative Studies Quarterly 18: 185-210.

Poole, Keith T. 2000. "Non-Parametric Unfolding of Binary Choice Data." Political Analysis 8: 211-37.

Poole, Keith T., and Howard Rosenthal. 1997. Congress: A Political-Economic History of Roll Call Voting. New York: Oxford University Press.

Rosenthal, Howard, and Erik Voeten. 2004. “Analyzing Roll Calls with Perfect Spatial Voting: France 1946-1958." American Journal of Political Science 48: 620-32.

Rothenberg, Lawrence S., and Mitchell S. Sanders. 2000. "Severing the Electoral Connection: Shirking in the Contemporary Congress." American Journal of Political Science 44: 316-25. Snyder, James. M., Jr. 1996. “Constituency Preferences: California Ballot Propositions, 197490.” Legislative Studies Quarterly 21: 463-88. 
Snyder, James. M., Jr. 2005. "Estimating the Distribution of Voter Preferences Using Partially Aggregated Voting Data." The Political Methodologist 13: 2-5.

Stratmann, Thomas. 1996. "How Reelection Constituencies Matter: Evidence from Political Action Committees' Contributions and Congressional Voting." Journal of Law and Economics 39: 603-35.

Swain, Carol. 1995. Black Faces, Black Interests. Cambridge: Harvard University Press.

Tate, Katherine. 2003. Black Faces in the Mirror: African Americans and Their Representatives in the U.S. Congress. Princeton and Oxford: Princeton University Press.

Thernstrom, Abigail. 1997. Whose Votes Count: Affirmative Action and Minority Voting Rights. Cambridge: Harvard University Press.

Weber, Ronald E. 2000. "Race-Based Districting: Does it Help or Hinder Legislative Representation?" Political Geography 19: 213-47.

Whitby, Kenny J. 1997. The Color of Representation: Congressional Behavior and Black Interests. Ann Arbor: University of Michigan Press.

Whitby, Kenny J., and George A. Krause. 2001. "Race, Issue Heterogeneity and Public Policy: The Republican Revolution in the $104^{\text {th }}$ US Congress and Representation of AfricanAmericans Policy Interests.” British Journal of Political Science 31: 555-72. 


\section{TABLE 1: Predicting Roll Call Vote Choices}

\begin{tabular}{|c|c|c|c|c|c|c|}
\hline \multirow[b]{2}{*}{ Legislators } & \multirow[b]{2}{*}{$\begin{array}{l}\text { No. of Non- } \\
\text { Unanimous } \\
\text { Votes }\end{array}$} & \multicolumn{2}{|c|}{ Strong Party Model } & \multicolumn{3}{|c|}{ Logits on Constituency Factor Scores } \\
\hline & & $\begin{array}{l}\text { Percent } \\
\text { Correctly } \\
\text { Classified }\end{array}$ & $\begin{array}{c}\text { Proportional } \\
\text { Reduction in } \\
\text { Error }\end{array}$ & $\begin{array}{l}\text { Percent } \\
\text { Correctly } \\
\text { Classified }\end{array}$ & $\begin{array}{c}\text { Proportional } \\
\text { Reduction in } \\
\text { Error }\end{array}$ & $\begin{array}{l}\text { Significant } \\
\quad L L R\end{array}$ \\
\hline $\begin{array}{l}\text { All Legislators } \\
N=80\end{array}$ & 1614 & 0.91 & .49 & 0.88 & 0.46 & .91 \\
\hline $\begin{array}{l}\text { Republican Legislators } \\
N=37\end{array}$ & 1061 & & & 0.80 & 0.18 & .42 \\
\hline \multicolumn{7}{|l|}{ Democratic Legislators } \\
\hline $\begin{array}{l}\text { All } \\
N=43\end{array}$ & 250 & & & 0.84 & 0.10 & .22 \\
\hline $\begin{array}{l}\text { Majority-White Districts } \\
N=22\end{array}$ & 200 & & & 0.83 & 0.13 & .13 \\
\hline $\begin{array}{l}\text { Majority-Minority Districts } \\
N=21\end{array}$ & 263 & & & 0.85 & 0.18 & .14 \\
\hline
\end{tabular}

Note: Table reports summary goodness-of-fit statistics from 5002 logit regressions (3388 on constituency factor scores; 1614 on party) predicting legislator's roll call vote choice. Number of observations $(N)$ included in each regression reflects size of subgroup of legislators. Entries in second column indicate the number of roll calls on which the identified subgroup of legislators was non-unanimous and for which separate logit regressions were estimated. Entries in last column are the proportions of roll calls for which likelihood ratio tests reject the hypothesis of a chance relationship between constituency preferences and vote choice at $p<.05$. 


\section{TABLE 2: Predicting Roll Call Vote Choices, Grouped By Committee of Origin}

\begin{tabular}{|c|c|c|c|c|c|c|c|c|c|}
\hline \multirow[b]{2}{*}{$\begin{array}{l}\text { Logit Models by } \\
\text { Committee of Origin }\end{array}$} & \multicolumn{3}{|c|}{ All Democrats } & \multicolumn{3}{|c|}{$\begin{array}{l}\text { Democrats from Majority-White } \\
\text { Districts }\end{array}$} & \multicolumn{3}{|c|}{$\begin{array}{c}\text { Democrats from Majority-Minority } \\
\text { Districts }\end{array}$} \\
\hline & $\begin{array}{l}\text { Percent } \\
\text { Correctly } \\
\text { Classified }\end{array}$ & $\begin{array}{c}\text { Prop. } \\
\text { Reduction } \\
\text { in Error }\end{array}$ & $\begin{array}{l}\text { Significant } \\
\quad \text { LLR }\end{array}$ & $\begin{array}{c}\text { Percent } \\
\text { Correctly } \\
\text { Classified }\end{array}$ & $\begin{array}{l}\text { Prop. } \\
\text { Reduction } \\
\text { in Error }\end{array}$ & $\begin{array}{l}\text { Significant } \\
\quad \text { LLR }\end{array}$ & $\begin{array}{l}\text { Percent } \\
\text { Correctly } \\
\text { Classified }\end{array}$ & $\begin{array}{c}\text { Prop. } \\
\text { Reduction } \\
\text { in Error }\end{array}$ & $\begin{array}{l}\text { Significant } \\
\quad \text { LLR }\end{array}$ \\
\hline Education & \multicolumn{3}{|c|}{$N_{R C}=12$} & \multicolumn{3}{|c|}{$N_{R C}=8$} & \multicolumn{3}{|c|}{$N_{R C}=11$} \\
\hline on Proposition 217 & 0.85 & 0.03 & 0.25 & 0.84 & 0.00 & 0.00 & 0.80 & 0.06 & 0.09 \\
\hline Judiciary & \multicolumn{3}{|c|}{$N_{R C}=32$} & \multicolumn{3}{|c|}{$N_{R C}=28$} & \multicolumn{3}{|c|}{$N_{R C}=30$} \\
\hline on Proposition 207 & 0.84 & 0.03 & 0.06 & 0.82 & 0.05 & 0.00 & 0.84 & 0.05 & 0.00 \\
\hline on Proposition 211 & 0.84 & 0.04 & 0.13 & 0.81 & 0.02 & 0.00 & 0.84 & 0.05 & 0.10 \\
\hline on Proposition 213 & 0.84 & 0.06 & 0.32 & 0.81 & 0.03 & 0.15 & 0.84 & 0.04 & 0.03 \\
\hline Health & \multicolumn{3}{|c|}{$N_{R C}=11$} & \multicolumn{3}{|c|}{$N_{R C}=5$} & \multicolumn{3}{|c|}{$N_{R C}=13$} \\
\hline on Proposition 214 & 0.89 & 0.10 & 0.27 & 0.83 & 0.08 & 0.00 & 0.87 & 0.06 & 0.00 \\
\hline on Proposition 215 & 0.89 & 0.11 & 0.18 & 0.84 & 0.14 & 0.00 & 0.87 & 0.02 & 0.15 \\
\hline on Proposition 216 & 0.89 & 0.13 & 0.27 & 0.84 & 0.16 & 0.20 & 0.87 & 0.06 & 0.00 \\
\hline Public Safety & \multicolumn{3}{|c|}{$N_{R C}=55$} & \multicolumn{3}{|c|}{$N_{R C}=36$} & \multicolumn{3}{|c|}{$N_{R C}=60$} \\
\hline on Proposition 213 & 0.84 & 0.14 & 0.65 & 0.84 & 0.09 & 0.12 & 0.79 & 0.14 & 0.35 \\
\hline on Proposition 215 & 0.83 & 0.14 & 0.40 & 0.84 & 0.07 & 0.22 & 0.81 & 0.15 & 0.32 \\
\hline
\end{tabular}




\section{TABLE 2 (cont.): Predicting Roll Call Vote Choices, Grouped By Committee of Origin}

\begin{tabular}{|c|c|c|c|c|c|c|c|c|c|}
\hline \multirow[b]{2}{*}{$\begin{array}{l}\text { Logit Models by } \\
\text { Committee of Origin }\end{array}$} & \multicolumn{3}{|c|}{ All Democrats } & \multicolumn{3}{|c|}{$\begin{array}{c}\text { Democrats from Majority-White } \\
\text { Districts }\end{array}$} & \multicolumn{3}{|c|}{$\begin{array}{c}\text { Democrats from Majority-Minority } \\
\text { Districts }\end{array}$} \\
\hline & $\begin{array}{l}\text { Percent } \\
\text { Correctly } \\
\text { Classified }\end{array}$ & $\begin{array}{c}\text { Prop. } \\
\text { Reduction } \\
\text { in Error }\end{array}$ & $\begin{array}{l}\text { Significant } \\
\text { LLR }\end{array}$ & $\begin{array}{l}\text { Percent } \\
\text { Correctly } \\
\text { Classified }\end{array}$ & $\begin{array}{c}\text { Prop. } \\
\text { Reduction } \\
\text { in Error }\end{array}$ & $\begin{array}{l}\text { Significant } \\
\text { LLR }\end{array}$ & $\begin{array}{l}\text { Percent } \\
\text { Correctly } \\
\text { Classified }\end{array}$ & $\begin{array}{c}\text { Prop. } \\
\text { Reduction } \\
\text { in Error }\end{array}$ & $\begin{array}{c}\text { Significant } \\
\text { LLR }\end{array}$ \\
\hline on Proposition 217 & 0.85 & 0.01 & 0.23 & 0.83 & 0.00 & 0.00 & 0.83 & 0.02 & 0.00 \\
\hline on Proposition 218 & 0.86 & 0.07 & 0.23 & 0.84 & 0.14 & 0.14 & 0.82 & 0.00 & 0.00 \\
\hline Local Government & \multicolumn{3}{|c|}{$N_{R C}=22$} & \multicolumn{3}{|c|}{$N_{R C}=20$} & \multicolumn{3}{|c|}{$N_{R C}=27$} \\
\hline on Proposition 217 & 0.79 & 0.07 & 0.18 & 0.78 & 0.06 & 0.10 & 0.82 & 0.07 & 0.15 \\
\hline
\end{tabular}

Note: Table reports summary goodness-of-fit statistics from logit regressions predicting legislator's roll call vote choice, using the districtwide vote on a related ballot proposition as the sole independent variable. Roll call votes are grouped by the standing committee to which the bill was assigned. Entries in columns three, six, and nine are the proportions of non-unanimous roll calls for which likelihood ratio tests reject the hypothesis of a chance relationship between the constituency measure(s) and vote choice at $p<.05$. $N_{R C}=$ Number of roll calls on which identified subgroup of legislators was non-unanimous; separate logit regressions were estimated for each roll call. 


\section{TABLE 3: Predicting Legislator Policy Orientation}

\begin{tabular}{|c|c|c|c|c|c|}
\hline \multirow[b]{2}{*}{ Legislators } & \multirow[b]{2}{*}{$\begin{array}{c}\text { Legislator's } \\
\text { Party }\end{array}$} & \multicolumn{2}{|c|}{ Constituency Factor Scores } & \multirow[b]{2}{*}{$N$} & \multirow[b]{2}{*}{$R^{2}$} \\
\hline & & $\begin{array}{l}\text { Consumer } \\
\text { Populism }\end{array}$ & $\begin{array}{l}\text { Economic } \\
\text { Liberalism }\end{array}$ & & \\
\hline \multirow{2}{*}{ All Legislators } & & $-.01(.01)$ & $-.14(.01)^{*}$ & 80 & .64 \\
\hline & $-.29(.02)^{*}$ & $-.00(.00)$ & $-.03(.01)^{*}$ & 80 & .92 \\
\hline Republican Legislators & & $-.02(.02)$ & $-.11(.02)^{*}$ & 37 & .43 \\
\hline \multicolumn{6}{|l|}{ Democratic Legislators } \\
\hline All & & $-.01(.00)^{*}$ & $-.01(.00)^{*}$ & 43 & .26 \\
\hline Majority-White Districts & & $-.00(.01)$ & $-.00(.01)$ & 22 & .04 \\
\hline Majority-Minority Districts & & $-.01(.00)^{*}$ & $-.00(.01)$ & 21 & .17 \\
\hline
\end{tabular}

Note: Cell entries in first three columns are coefficients (and standard errors) from OLS regressions. (Coefficient on constant term not shown; no other predictors included in models.) The dependent variable is the legislator's first dimension optimal classification score. ${ }^{*} p<.05$ 


\section{FIGURE 1: Estimated Constituency Preferences}

CA Assembly Districts, November 1996
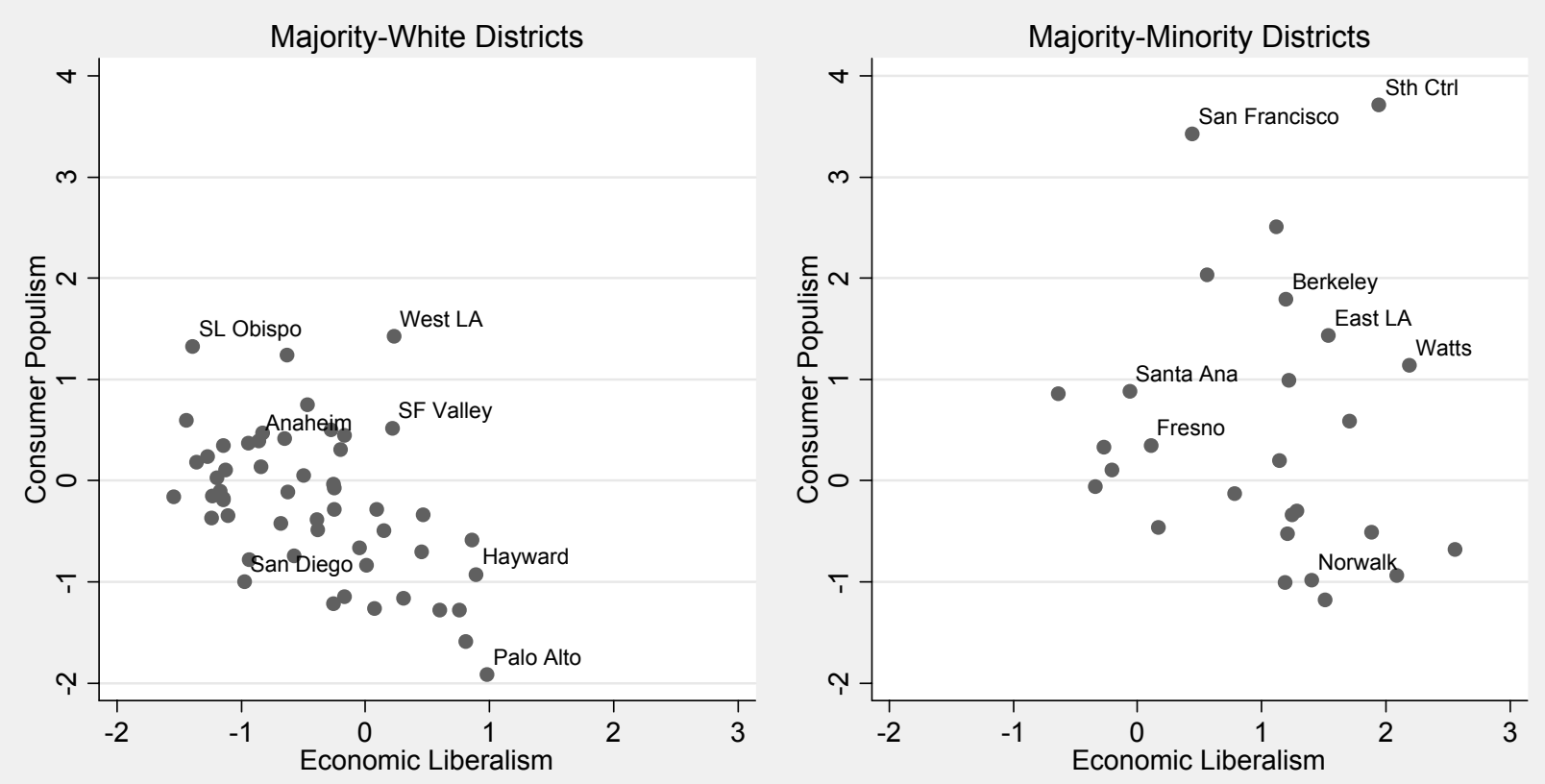

Note: Graphs plot each district's maximum likelihood factor scores 


\section{FIGURE 2: Distribution of Legislator Ideal Points}

CA Assembly, 1997-1998

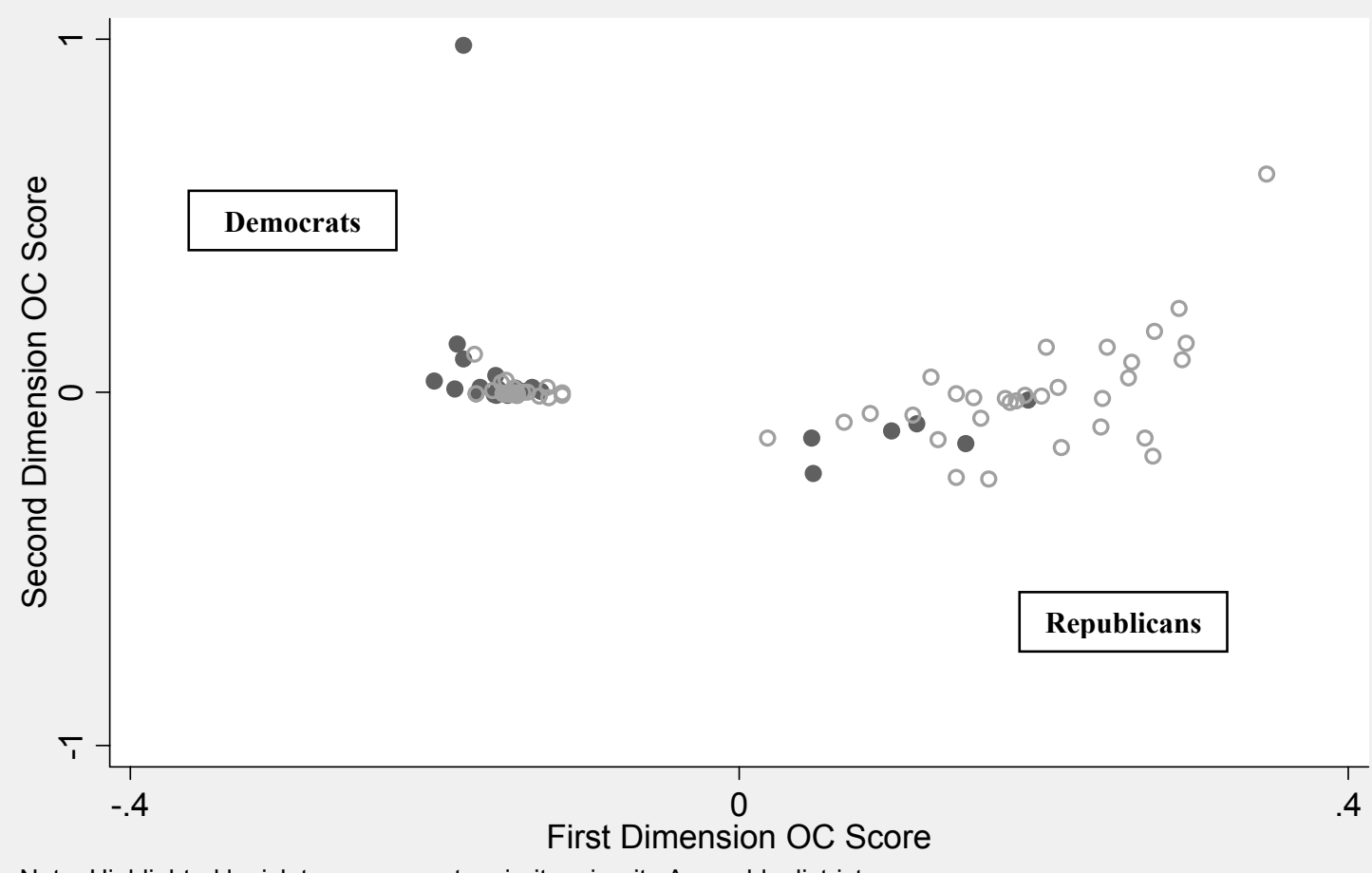

Note: Highlighted legislators represent majority-minority Assembly districts. 